Available online at website :

http://e-journal.adpgmiindonesia.com/index.php/jmie

JMIE: Journal of Madrasah Ibtidaiyah Education, 4(1), 2020, 39-52

\title{
PROJECT-BASED LEARNING - LITERACY IN IMPROVING STUDENTS' MATHEMATICAL REASONING ABILITIES IN ELEMENTARY SCHOOLS
}

\author{
Zaenal Abidin'), Arief Cahyo Utomo'), Vira Pratiwi ${ }^{3)}$, Laely Farokhah ${ }^{4)}$ \\ Universitas Muhammadiyah Surakarta1), 2), Universitas Bhayangkara Jakarta3) \\ Universitas Muhammadiyah Jakarta ${ }^{4)}$
}

Email: za825@ums.ac.id¹), acu234@ums.ac.id²),vira.pratiwi@dsn.ubharajaya.ac.id³),

laelyfarokhah@umj.ac.id ${ }^{4}$

Naskah diterima : 13 Maret 2020, direvisi : 24 April 2020, disetujui : 30 April 2020

\begin{abstract}
The lower mathematical reasoning abilities of elementary school students are the background of this research. This happens because students have not been properly facilitated to develop the ability mathematical of reasoning. Mathematics learning can develop reasoning ability well because mathematics learning has systematic concepts and conceptual relationships. This will have an impact on logical, systematic and rational ways of thinking. Therefore, teachers must be able to choose learning models that can facilitate the ability of mathematical reasoning. One learning model that can be used is the literacy project-based learning model. This study aimed to determine the effectiveness of improving the ability of mathematical reasoning students who obtain literacy project-based learning. The design of this research was used pretest-posttest non-equivalent control group. Based on research results, conclusions can be drawn about the effectiveness of learning that includes n-gain, minimum completeness criteria, and mastery learning. Literacy projectbased learning has been effective in facilitating reasoning abilities. That is because literacy project-based learning can present contextual material with literacy works that are made and invited to carry out the process of thinking about the use of mathematical contexts in daily life. Furthermore, students can connect mathematical material with real-life contexts and can make reasoning to interpret learning well.
\end{abstract}

Keywords: Project-Based Learning, Literacy, Reasoning Mathematics, Elementary Schools

Pengutipan: Abidin, Zaenal, dkk. (2020). Project-Based Learning - Literacy In Improving Students' Mathematical Reasoning Abilities In Elementary Schools. JMIE: Journal of Madrasah Ibtidaiyah Education,4(1), 39-52. jmie.v4i1.170. 


\section{INTRODUCTION}

In the 21 st century, the development science and technology demanded to able to think a high level that includes the critical, logical, creative. Trilling and Fadel (2009) stated education in century 21 st focuses on four competencies, namely the ability to understand the higher, the ability to think critically, the ability to collaborate, and the ability to communicate.

The situation of students in Indonesia inversely proportional to the demands of the century to the $21 \mathrm{st}$. The competencies students in Indonesia is still very low. It based on results of Trends in International Mathematics and Science Study (TIMSS) in the year 2015 which shows the results of tests Indonesian students still were in position four bottom (IEA's Team, 2015). The results of tests that showed that student elementary school in Indonesia is still less well within the ability of mathematics.

Results in the TIMSS on to explain that elementary school students in Indonesia are still very low in the ability of reading comprehension in the field of science and mathematics, as well as the ability to solve problems that relate to the context of life every day. Students are less facilitated by both the development of the ability of reasoning mathematically students. Mathematics reasoning can develop the ability to think logically which becomes the demands of the century to -21 (Abidin, 2017). Problems that occur because students more often work about the routine that only trained memory (Abidin, 2016). Besides that, students are not allowed to seek and find knowledge itself so that the ability of reasoning mathematically students have not facilitated to the maximum.

Based on a limited study conducted by researchers in one of the elementary schools, it is stated that mathematics learning is very difficult to be connected with other mathematical material or other subject matter. This is because the teacher does not feel accustomed to learning mathematics like that. Meanwhile, as we know the demands of the 2013 Curriculum is the connection between one subject and another or one material with another material known as Thematic Integrated (Kemendikbud, 2013). Besides, another problem is that students feel confused when learning seems like there is no separation. This is because students have not been facilitated to develop their reasoning abilities, especially in this case students' mathematical reasoning abilities. Besides, the 2016 revised edition of the 2013 curriculum is no longer a subject of mathematics in thematic learning (Kemendikbud, 2016). This causes fewer opportunities for children to learn mathematics holistically with other lessons so that children are less facilitated with good reasoning abilities.

Learning in the 2013 revised edition of the 2013 curriculum, presenting material from the concept of material not from a problem (Kemendikbud, 2016). So those students are less facilitated the ability of reasoning mathematics. Students are not given problems to develop the ability to guess, think logically and infer information. The context of the lives of every day into a thing that is important in developing the ability of reasoning the students, the students 
will think is inductive and deductive are trained to think logically (Mahdiansyah and Rahmawati, 2014). So that with the revision of the curriculum is, causing not yet facilitated ability reasoning of students with good.

Learning which explains the reasoning can develop patterns of thought a child in a logical, inductive and deductive (Prastowo, 2019). Learning and understanding the concept can be initiated by inductively through the experience of the event real. Learning should be able to connect between the knowledge of students and the context of the problem. So that teachers should be the determined design of learning which can facilitate the ability of mathematical reasoning.

To overcome this problem, it is clear that learning must have a representative media that can connect student knowledge in real situations and learning material. In addition, there must be a model that can develop old and new knowledge of students and facilitate students' mathematical connection abilities. In order to fulfil all competencies, a teacher should be able to become a facilitator and mediator in meeting the needs of students related to 21st-century competencies. Therefore, the teacher must be able to choose the right learning model to fulfil his competence.

In the learning process, the teacher plays an important role in facilitating students. The teaching used by the teacher is inseparable from the learning model that he uses. The learning model is a plan that is used to shape the curriculum, make learning material, and become a learning guide (Joyce, Weil, \& Calhoun, 2009). Furthermore, the model is translated into a broad unity of learning systems that contain specific philosophical foundations or theories of learning with pedagogical methods (Novalia, 2017). So the learning model is a conceptual framework used in learning.

As the development of learning in the 21 st century, the learning model used by teachers also experienced development. In bridging the competencies students must master, teachers are required to use learning models that can facilitate students to think critically, creatively, and innovatively. Student success in learning is not only measured by how they remember the material given by the teacher, but how much students understand the concepts given by the teacher. There is a significant difference between remembering and understanding. In Bloom's taxonomy known as Taxonomy of Learning (Trilling \& Fadel, 2009), given that it is in the C1 phase, namely the basic abilities in the cognitive domain. While understanding is in phase $\mathrm{C} 2$, which is a higher stage than remembering. To make students able to understand the concepts given by the teacher, it takes a learning model that can support this.

Constructivism experts hold that meaningful learning is learning that can make students find their own concepts, this is in accordance with the opinions of Glaserfeld and Matthews (in Siregar and Nara, 2010). The teacher's role is the facilitator in the process of finding the concept. A concept is a tool used by humans to organize unlimited impressions using the 
senses (Swidler, 2014). When students can develop their own concepts, the teaching material provided will be understood by students. Some learning models that give students the opportunity to develop their own concepts and are encouraged in learning the 2013 Curriculum are the PJBL-Literacy Model.

Learning Model is a plan that is used to form the curriculum, making the material learning, and become the guidelines of learning (Joyce, Weil, and Calhoun, 2009 ). Model is translated into a broad unity of learning systems that contain specific philosophical foundations or theories of learning with pedagogical methods ( Nugroho, 2018). So the learning model is life in making a learning design. Model Project Based Learning helps students to get used to thinking in inductive (Julie Johnson, 1992 ). Model Project Based Learning is a model that is very suitable for all levels of education because according to Etherington (2011) describes the learning with Project-Based Learning can make students understand a problem and seek a solution it so that students learn to be meaningful. Things are in line with research Firdaus, Wahyudin, Herman (2017) which explains that learning with Project-Based Learning can make a child connect the knowledge of students and the context of life every day with good.

Literacy is very important in 21 st-century learning. In line with this, ConcannonGibney and McCarthy (2012) state that learning in the 21st century must always support literacy activities so that learning can be meaningful and provide skills to students. While Mckee and Ogle (2005) looked at literacy are all skills, in use reading, writing, listening and speaking are efficient for me $\mathrm{m}$ stimulus $\mathrm{k}$ Capacity of thinking $\mathrm{d}$ late communicate.

McConachi, et al. (2010) describe a model of learning P J BL- Literacy as learning that demand use reading, logic, research, speaking and writing to learn content knowledge is complex. This opinion is in line with Rahman (2018) who states that learning PJBL- Literacy is learning that provides a challenge for students to study and apply practical literacy that serves as a mediating tool for learning various concepts across the curriculum.

Shyyan, Thurlow, and Liu (2008) explain reading learning that is integrated with mathematics has been able to improve students' abilities in mastering mathematical concepts. While Tan (2011) describes the ability of students to understand the concept of experiencing developments that significantly when learning to apply skills of literacy. More further, Swanson, et al. (2011) explain that learning literacy can improve the ability to read the students at the same time improving the understanding of students on the material taught.

Based on several studies in the above efforts in developing the ability to learn and competence of the century to 21 on self- students can be done by applying the skills PJBLLiteracy. Learning model PJBL- Literacy students will be able to think critically, creatively and able also to collaborate and communicate it effectively. The steps of learning PJBL- Literacy 
has been developed by Bill and Jamar (2010), measures of learning PJBL- Literacy can be seen in Table 1 at the bottom of this.

Table 1 Learning Syntaxs

\begin{tabular}{ll}
\hline \multicolumn{1}{c}{ Step } & \multicolumn{1}{c}{ Student Activities } \\
\hline Set up & Students have explained the plan, objectives and learning \\
& activities to be carried out. \\
Explore & Students do the activities of exploration as an individual in \\
& completing the task. \\
& Students carry out cooperation with the friends' group \\
& separately completed the tasks are more complex. \\
& Students make conclusions with a literacy work (Pop-ups, \\
& Posters, Comics ) \\
& Students discuss various solutions \\
Share and Discuss & Students explain the work that has been done \\
Presenting &
\end{tabular}

From all the above description, no research focuses on PJBL-Literacy Model Learning in Primary Schools on Mathematics which is focused on mathematical connection skills. So that in this study will examine the Effectiveness of PJBL-Literacy learning model in improving mathematical reasoning skills of elementary school students.

\section{RESEARCH METHODS}

In this study using the experimental method with a quasi-experimental design. This study involved two sample groups consisting of a control group and an experimental group. According to Cresswell (2015), a quasi-experimental research method consists of several types of designs all of which have strengths and strengths. Design studies are used by researchers is a design that has a draft Pretest-Posttest Control Group Design. In this study, Pretest is given at the beginning before learning while posttest is given at the end after all the learning is completed.

Population is a collection of all measurements, objects, or individuals that will be the main focus in a study. The population selected in this study were all students of class $\mathrm{V}$ Elementary School in the even semester of the academic year 2017/2018 in the region of Cileunyi District Bandung Regency.

The sample selection is done not randomly, but rather the sample is chosen based on incidental sampling techniques. The incidental sampling is a sampling technique based on a coincidence and adjusted to the needs in the sense that the sample is in accordance with the research to be carried out. The private elementary school was chosen and determined as a research sample by researchers because it has many parallel classes with homogeneous 
academic abilities. In addition, these elementary schools are still using and are consistent in applying the 2013 Curriculum and become the 2013 Curriculum Model School.

The instrument used in this study was a test instrument. The test instrument in this study was a question in the form of a description to measure students' mathematical reasoning abilities. The analysis technique used in the study contained several data analyzes that were adjusted to the formulation of the problem and its hypothesis. More clearly can be seen in Table 2 below:

Tabel 2 Data analysis

\begin{tabular}{llll}
\hline No & The problem & Data analysis & Information \\
\hline 1 & Which one is better for & One way t test on & The prerequisite tests \\
& improving students' & mathematical reasoning & performed are the Normality \\
mathematical reasoning & gain scores & and Homogeneity Tests \\
abilities that obtain PJBL- & & \\
Literacy or conventional? & & \\
\hline
\end{tabular}

\section{RESULT AND DISCUSSION}

The results in this study take gain data as one indicator in measuring learning effectiveness. As for the value of the mathematical reasoning gain results can be seen in Table 3 below:

Table 3 Mathematical Reasoning Values

\begin{tabular}{|c|c|c|c|c|c|c|}
\hline \multicolumn{7}{|c|}{ Descriptive Statistics } \\
\hline Pretest Score & $\mathbf{N}$ & Minimum & Maximum & Sum & $\begin{array}{c}\text { The } \\
\text { mean }\end{array}$ & $\begin{array}{c}\text { Std. } \\
\text { Deviation }\end{array}$ \\
\hline Experiment Class & 24 & 66.7 & 100 & 1904 & 79.32 & 9.2 \\
\hline Control Class & 24 & 45.8 & 68.7 & 1372 & 57.15 & 7.0 \\
\hline
\end{tabular}

Based on Table 3 at the top, can be seen that the increase in the ability of students' classroom experiments and classroom control differ much. It is can be seen from the acquisition of the average score of the experimental class at 79.32 and the average s choir class controls 57.15. It is seen that the average score gain classroom experiment is large compared with the average score gain control by a margin of 22.17. Besides, the experimental class students found to have a value of gain of 100 . This illustrates that the in-house expertise of learning in class download can improve students' mathematical reasoning abilities significantly. In measuring the significance of the difference, an average difference test will be performed on the results of the gain. The hypothesis and hypothesis counter that is used, namely : 
$\mathrm{H}_{0}$ : increase the ability of one group of students is not better than group 2

Ha: increase students' abilities better than group 1 than group 2

Table 4 Results of Tests for Difference in Reasoning Gain

\begin{tabular}{ccccc}
\hline & $\begin{array}{c}\text { Sig. } \\
(2 \text { tailed })\end{array}$ & $\begin{array}{c}\text { Sig. } \\
(1 \text { tailed })\end{array}$ & Decision & Information \\
\hline PJBL - & 0.000 & 0.000 & $\mathrm{H}_{0 \text { is }}$ rejected & $\begin{array}{c}\text { Improving the ability } \\
\text { of reasoning PjBL- } \\
\text { Conventional }\end{array}$ \\
& & & $\begin{array}{c}\text { Literacy better } \\
\text { than conventional }\end{array}$ \\
& & & & \\
\end{tabular}

From the results of testing hypotheses by statistical Table 4 explains that there are differences in the ability of reasoning mathematically students who acquire learning PJBLliteracy with Conventional. The PJBL-Literacy Model is better in facilitating the improvement of students' mathematical reasoning abilities compared to conventional learning. In determining the effectiveness, three things are seen, namely the average score above the $\mathrm{KKM}$, the average gain, and mastery learning. Learning PJBL- literacy has an average score of 80 , the gain of 79 and $83 \%$ completeness study. It can be assumed that literacy-based project learning has been effective because the average score is more than KKM $(80>70)$, the gain is in the high category and the learning completeness is more than $80 \%$.

From the results of testing hypotheses by statistical, hypotheses were proposed as empirical in research is accepted which means that there are differences in the ability of reasoning mathematically students who acquire learning PJBL-Literacy with the Conventional. Besides, there are significant differences in the improvement of mathematical reasoning abilities among students who obtain learning PJBL-Literacy with Conventional. The PJBLLiteracy Model is better in facilitating the improvement of students' mathematical reasoning abilities compared to the Conventional Model.

Improved the capacity of reasoning mathematically students in the class experiment there are differences in the ability of reasoning students in grade control, the case is caused because the class experiment process of learning has always stressed the interconnectedness of matter of mathematics to materials math more, the material mathematics with material eyes the lessons of others, and the material mathematics with real life. The process of learning proficiency level has an impact on patterns of thinking students who are always trying to look at the relationship of the matter of mathematics with all aspects so that the ability of reasoning mathematically students can become better because of habituation to the process of learning what to do. While the grade control process of learning is done with the purpose of the student can construct knowledge of the results of observations were focused on the matter of mathematics without given the opportunity to see the relevance of material math with aspects 
of another. It 's resulted in the students in the class control is not familiar with the existence of a link between the material math with aspects of others it must be socialized and shown. This is very much following the opinion of Eggen P, and Kauchak D (2012) who explained that good learning not only builds students' knowledge but must be very meaningful and always relate to everyday life.

PJBL-literacy model capable of improving the ability of reasoning mathematically students are significant. That is because the PJBL-Literacy Model provides daily problems as a learning context. This is very consistent with the results of research from Zheng A and Zhou Y (2011) which states that learning with the PJBL-Literacy Model can make students think more deeply and learn to be very meaningful.

It is following the theory of learning social are proposed by Glaserfeld and Matthews (in Siregar and Nara $2010 \mathrm{hlm.39}$ ) argued that " Knowledge that is owned by someone is the result of construction ( formation) of its own ". More advanced Piaget (in Siregar and Nara $2010 \mathrm{hlm} .39$ ) argued that " Knowledge is the creation of man which is constructed from experience, the process of formation runs continuously constantly and every time occurred reconstruction because of their understanding of the new ". PJBL Model Learning can train students' thinking maturity through four stages of learning. By setting the cooperative, make every student has the sole responsibility of the same to understand every teaching that is done by the group. each stage of the PJBL model greatly affects the maturity of thought which gained the students to able to increase the ability of reasoning mathematically students.

From the results of observation during the administration of a treatment that is done, several things affect the ability of reasoning mathematically students between students who get learning with Model PJBL -Literasi and students who obtain a different lesson. Among them is the activity of the student during the process of learning takes place, in a class experiment is the activity of the students tend to be very enjoyable and the students are very active in the process to share and discuss. This is very much following the results of Ojose (2011) research which explains that in learning PJBL- Literacy can greatly increase student motivation to learn because of the fun discussion activities. Discussions on learning with Model PJBL- Literacy is very interactive and communicative because all students are required to be active and focus on the issues discussed. These activities can be seen in Figure 1 below. 


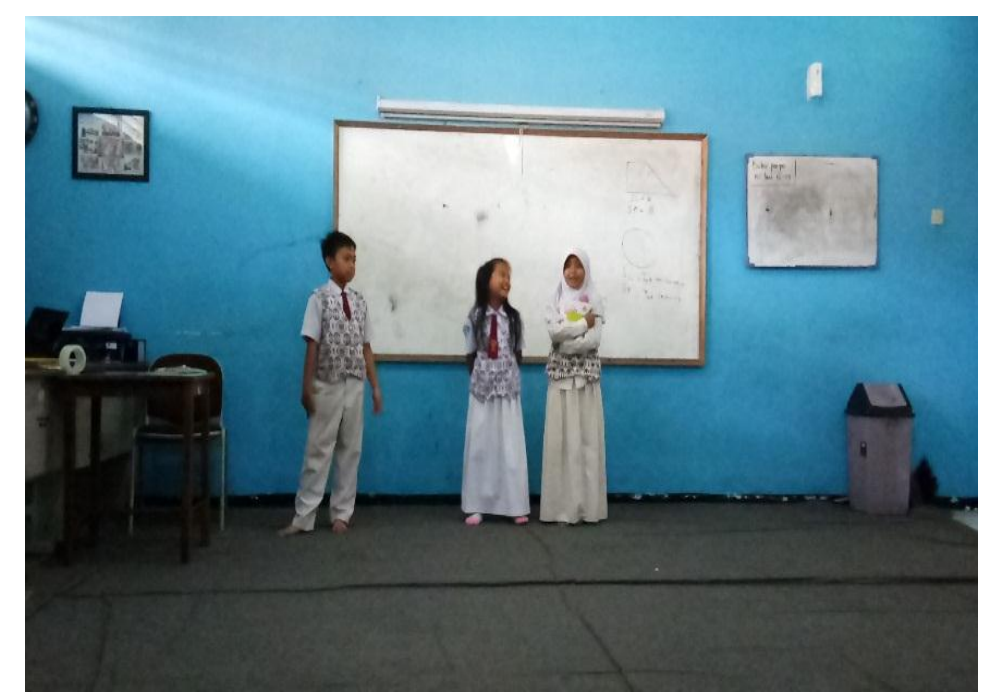

\section{Figure 1. Presentation on Learning Process PJBL -Literacy}

In the learning process in the experimental class with Model PJBL- Literacy, the nuances of learning that are carried out do not seem rigid and focused on mathematical material while still not ignoring the essence of the content of mathematical material. So when the learning process, students do not feel that they are learning mathematical material but they are learning material that contains mathematics and other aspects that show that mathematics material has very universal flexibility and understands the usefulness of mathematics for life. Inversely inverted with the respect that, students in grade control feel that math is a material focus that so does not need to look at aspects of the other. This is very consistent with the results of research from Wardono (2014) which explains that learning with Model PJBLLiteracy makes children challenged to solve problems without feeling they are learning.

The PJBL-Literacy Model also has a good influence in facilitating the improvement of students' mathematical reasoning abilities. In this study, students are very happy and active in learning which makes their abilities increase significantly. Model PJBL-Literacy also can improve students' mathematical reasoning abilities significantly. This is following the results of research Tai CH, Leou S, Hung JF (2014) which explains that literacy is very important in learning mathematics because it can improve the ability and understanding of students in mastering the concepts of mathematical material.

Also, the learning model with the Model PJBL-Literacy students is very happy because students have projects that must be done. Students learn by linking mathematical material with real-life, associating mathematical concepts with other learning concepts with the activity of making literacy projects. In this project, students are required to connect mathematical concepts with everyday life and other learning concepts. These activities can be seen in Figure 2 below. 

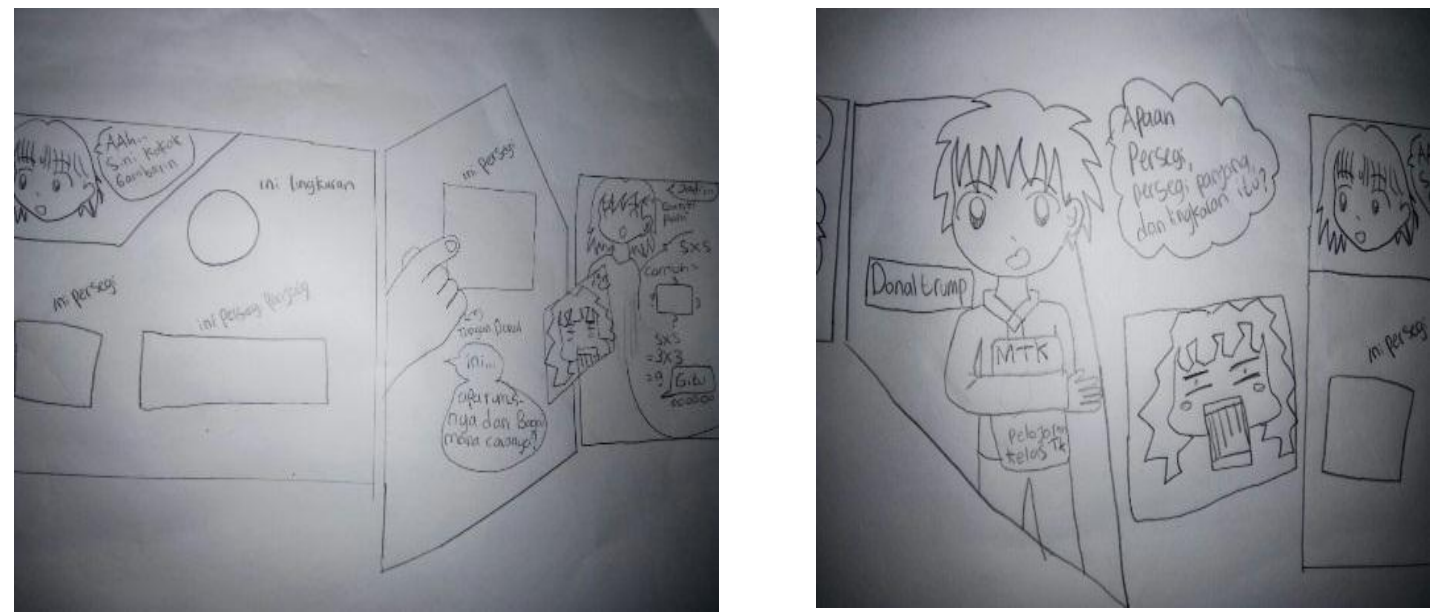

\section{Figure 2. Comics by PJBL-Literacy}

In learning with the PJBL-Literacy Model students are greatly facilitated in mathematical reasoning abilities. This can be seen from the activities that are always demanding for reasoning ability in each stage of PJBL-Literacy learning. This is very consistent with Levenberg research (2015) which explains that literacy activities can increase students 'sensitivity to the surrounding context and can increase students' understanding of mathematical material and its relation to daily life.

From all of the above, it can be drawn that the learning of the PJBL Model is a better model in facilitating students' mathematical reasoning abilities compared to Conventional classes. This can be seen from the statistical test which shows that Ho is rejected, which means an increase in class reasoning ability with the PBL model and the PJBL-literacy model is better than the Conventional class.

Literacy project-based learning has an average score of 80 , a gain of 69 and an $83 \%$ mastery learning. It can be assumed that literacy-based project learning has been effective because the average score is more than KKM $(80>70)$, the gain is in the high category and the learning completeness is more than $80 \%$. This can be illustrated in Figure 3 about student learning outcomes below. 
4. Bhanu mempunyai 2 kotak makanan berbentuk kubus dan balok. Kedua kotak tersebut akan akan diisi dengan makanan yang sama. Panjang sisi kubus adalah $18 \mathrm{~cm}$, sedangkan kotak berbentuk balok mempunyai panjang $20 \mathrm{~cm}$, lebar $16 \mathrm{~cm}$, dan tinggi $18 \mathrm{~cm}$. Kirakira manakah kotak yang lebih banyak menampung makanan? Berikan alasanmu!?

$$
\begin{aligned}
& \text { balok } \\
& \text { karema: } \\
& \text { vkubs }=18 \times 18 \times 18 \\
&=4 \mathrm{~g} 68 \\
& \text { Vbalok }=20 \times 16 \times 18 \\
&=5760
\end{aligned}
$$

Figure 3. PJBL-Literacy student learning outcomes

n Figure 3 above, it can be seen that students can answer correctly. However, students have not been able to provide logical reasons to determine the broader structure. Students can determine which spaces are wider, but students cannot make logical statements that can support the answer. Even so, this literacy-based learning project has been able to lead students to think logically and make decisions, even though children cannot argue. This shows that literacy-based project learning has been effective in improving students' mathematical understanding abilities.

Conventional learning has an average score of 71 , a gain of 57 and a $70 \%$ mastery learning. It can be assumed that Conventional learning has not been effective, because mastery learning is still below $80 \%$ even though on average it is more than KKM $(71>70)$ and the gain is in the medium category. This can be proven by student learning outcomes in Figure 4 below.

1. Sebuah kotak berbentuk kubus memiliki warna sisi yang berbeda pada setiap sisinya. Jika sisi berwarna merah bertolak belakang dengan sisi berwarna biru dan sisi warna kuning bertolak belakang dengan sisi warna hijau. Bagaimanakah kira-kira jaring-jaring dari kotak tersebut?

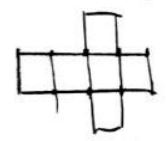

Figure 4. Conventional learning outcomes 
In Figure 4 above, it can be seen that students have not been able to reason properly. This can be seen from students who have not been able to determine the colour in each part of the webs. Students at this stage only understand the shape of the cube nets, have not been able to determine the colour of colour in each part. Students have not been facilitated in thinking at a high level, so students cannot solve these problems. Conventional learning cannot facilitate effectively in improving students' mathematical reasoning abilities.

\section{CONCLUSION}

There are differences in mathematical reasoning abilities between students who obtain literacy-based project learning and Conventional learning. This happens because of several factors, one of which is in the literacy-based learning project there is a discussion process that demands higher-order thinking skills from students so that it can indirectly facilitate the ability of reasoning properly. It is this discussion activity that makes the difference in abilities between classes that get literacy-based project learning and abilities that get other learning. Also, literacy-based project learning is better than Conventional learning in facilitating mathematical reasoning abilities because students are facilitated to do high order thinking skills when planning and making projects.

There are differences in increasing mathematical reasoning abilities between students who obtain learning using literacy-based project learning and Conventional learning. With everyday problems presented as contexts in learning, students make meaningful thinking processes until students can solve and find solutions to problems. This is exactly what can significantly improve students' mathematical reasoning abilities. Also, literacy-based project learning is a good and effective learning model in facilitating students in improving mathematical reasoning abilities. That is because students are invited to make reflections in the form of daily journals that make them know where their abilities are and to what extent and which parts they need to improve in their thought processes.

In the context of the study, the researcher recommends to investigate more about related models PJBL- Literacy, it is seen the results of research which show that the model is very able to make students creative and pleased with not rule out the essence of the material that is presented.

\section{REFERENCES}

Abidin, Y. (2013). Desain Sistem Pembelaran dalam Konteks Kurikulum 2013. Bandung : Refika Aditama.

Abidin, Z. (2016). Mathematical Learning Activity Using Connecting Organizing Reflecting Extending (Core) Models To Improve Mathematical Connection Skills . Proceeding International Conference and Technology, UM Malang. Vol. 2: 68-79. 
Abidin , Z and Jupri , A. (2017). The Use of Multiliteration Model to Improve Mathematical Connection Ability of Primary Schools on Geometry. International E-Journal of Advances in Education, 3 (9), 603-610.

Andi Prastowo. (2019). Menumbubkan Keterampilan Berpikir Tingkat Tinggi Melalui Buku Tematik. Kelas Rendah di Sekolab Dasar / Madrasah Ibtidaiyah. JMIE: Journal of Madrasah Ibtidaiyah Education,3(2), 2019, 100-117. jmie.v3i2.126.

Bill, V. and Jamar, I. (2010). " Disciplinary Literacy in Mathematics Classroom" in Content Matters: A Disciplinary Literacy Approach to Improving Student Learning. San Francisco: Jossey-Bass A Wiley Imprint.

Concannon-Gibney, T. \& McCarthy, MJ (2012). "The Explicit Teaching of Reading Comprehension in Science Class: a Pilot Professional Development Program". Improving Schools. 15 (1), 73-88.

Cresswell, J. (2015). Educational Research: Planning, implementing and Evaluating Qualitative and Quantitative Research. Yogyakarta: Student Library

Eggen P, dan Kauchak D (2012). Strategi dan Model Pembelajaran. Jakarta: Indeks.

Etherington MB (2011). Investigative Primary Science: A Problem-Based Learning Approach. Austr. J. Teacher Educ. 36(9):36-57

Firdaus, MF, Wahyudin ., Herman, T. (2017). Improving primary students' mathematical literacy through problem-based learning and direct instruction. Academic Journal. Vol. 12 (4), pp. 212-219

Ivanic, R. (2009). "Bringing Literacy Studies into Research and Prospects" in The Future of Literacy Studies. New York: Palgrave MacMillan.

Joyce, B., Weil, M., \& Calhoun, E. (2009). Models of Teaching: Models of Teaching ( Issue 8). Yogyakarta: Student Library.

Kemendikbud (2013). Bahan Ajar Pengelolaan Pembelajaran Terpadu. Jakarta : Kemendikbud.

Kemendibud (2016). Revised Curriculum 2013: Mathematics separated from thematic. [Online]. Available: https: /kemendikbud.go.id/kemdikbud/

Levenberg I (2015). Literacy in Mathematics with "Mother Goose". Int. J. Learn. Dev 5 (1): 27 32.

Mahdiansyah dan Rahmawati (2014). Mathematical Literacy of Students at Secondary Education Level: An Analysis Using International Test Design with Indonesian Context. J. Pendidikan dan Kebudayaan. 20(4):452-469.

McConachi, SM, et al. (2010). Content Matters: A Disciplinary Literacy Approach to Improving Student Learning. San Francisco: Jossey-Bass A Wiley Imprint.

McKee, J. and Ogle, D. (2005). Interesting Instruction Literacy and Science. New York: The Guilford Press. 
NCTM (2012). Principles and Standards for School Mathematics Volume 1. Michigan: National Council of Teachers of Mathematics.

Novalia, E. (2017). “Analisis Kemampuan Literasi Matematika dan Karakter Kreatif pada Pembelajaran Synectics Materi Bangun Ruang Kelas VIII". Unnes Journal of Mathematics Education

Nugroho, R. A. (2018). HOTS (Kemampuan Berpikir Tingkat Tinggi: KOnsep, Pembelajaran, Penilaian, dan Soal-Soal). Jakarta: Gramedia Widiasarana Indonesia.

OECD (2016) PISA : Science and Math Competencies for Tomorrow's World Volume 1 Analysis. Canada : OECD.

Ojose, B. (2011). "Mathematics Literacy. Are We Able to Put The Mathematics We Learn Into Everyday User?". Journal of Mathematics Educations, 4(1): 89-100

Olge, D. et al. (2007). Building Literacy in Social Studies: Strategies for Improving Comprehension and Critical Thinking. Alexandria: ASCD.

Rahman (2018). Literacy Skills in Elementary Schools. Presented in National Workshop and Seminar Developing Literacy of Dyslexic Children in Inclusive Primary Schools. July 21, 2018

Shyyan, et al (2008). Instructional Strategies for Improving Achievement in Reading, Mathematics, and Science for English Language Learners. Assessment for Effective Intervention. 33 (3). 145-155.

Siregar, E. dan Nara, H. (2010). Teori Belajar dan Pembelajaran. Bogor: Ghalia Indonesia.

Swanson, E., et al. (2011). "Applying a Cohesive Set of Comprehension Strategies to Content Area Instruction". Intervention in School and Clinic. 46 (5), 266-272.

Swidler, L. (2014). Dialogue Institute: "Whole Child Education” Exercise in Problem Based Learning Dialogue for Interreligious Understanding.

Tai CH, Leou S, Hung JF (2014). Mathematical Literacy of Indigenous Students in Taiwan. Int. Res. J. Sustain. Sci Eng. 2 (3): 1-5.

Tan, M. (2011). "Mathematics and Science Teachers' Beliefs and Practices Regarding The Teaching of Language in Learning Content". Language Teaching Research. 15 (3), 325342.

Trilling, B. \& Fadel, C. (2009), 21 st Century skills. San Francisco: Jossey-Bass A Wiley Imprint. Wardono. (2014). "The Realistics Learning Model With Character Education And PISA Assesment To Improve Mathematics Literacy". International Journal of Education and Research, 2(7): 361-372

Zheng A, dan Zhou Y (2011). An Inductive, Interactive And Adaptive Hybrid Problem-Based Learning Methodology: Application to Statistics. J. Eng. Sci. Technol. 6(5):639-650. 